\title{
Sinergitas dan Kinerja Organisasi Perangkat Daerah (OPD) dalam Pelaksanaan Kebijakan Sektor Pertanian di Kabupaten Timor Tengah Utara
}

\author{
Dian Festianto ${ }^{\mathrm{a}}$, Marthen Patiung ${ }^{\mathrm{b}}$, Medan Yonathan Mael ${ }^{\mathrm{c}}$, Agustinus Longa Tiza ${ }^{\mathrm{d}}$ \\ ${ }^{a}$ Fakultas Ilmu Sosial dan Ilmu Politik, Universitas Timor, Kefamenanu, TTU - NTT, Indonesia. email: d festianto@yahoo.com \\ ${ }^{b}$ Fakultas Ilmu Sosial dan Ilmu Politik, Universitas Timor, Kefamenanu, TTU - NTT, Indonesia. email: patiungmarthen@yahoo.com \\ ${ }^{c}$ Fakultas Ilmu Sosial dan Ilmu Politik, Universitas Timor, Kefamenanu, TTU - NTT, Indonesia. email: medanmael123@gmail.com \\ ${ }^{d}$ Fakultas Ilmu Sosial dan Ilmu Politik, Universitas Timor, Kefamenanu, TTU - NTT, Indonesia.email: aguslongatiza@gmail.com
}

\section{Article Info}

Article history:

Received 8 April 2018

Received in revised form 19 Oktober 2018

Accepted 29 November 2018

DOI:

https://doi.org/10.32938/sc.v4i02.461

\section{Keywords:}

Sinergitas

Kinerja

Kebijakan

Sektor Pertanian

\section{Abstrak}

Penelitian ini mendeskripsikan sinergitas Organisasi Perangkat Daerah (OPD) dalam pelaksanaan program Sari Tani sebagai program unggulan Bupati Timor Tengah Utara (TTU), yang dilaksanakan dengan pendekatan studi kasus bersifat deskriptif analitis dengan tujuan membangun model alternatif dalam akselerasi kebijakan pertanian dalam rangka mewujudkan kedaulatan pangan di KabupatenTTU. Ukuran sinergitas meliputi intensitas koordinasi dan sinkronisasi antar OPD mulai dari tahap formulasi sampai implementasi kebijakan.Pengumpulan data primer melalui wawancara dengan pemangku kebijakan dengan menggunakan teknik purposive sampling, untuk memenuhi objektifitaspenelitian masyarakat petani diwawancara sebagai informan tambahan dengan teknik cluster sampling, sedangkan data sekunder diperoleh melalui institusi terkait. Observasi juga dilakukan untuk memahami sikap dan perilaku subyek penelitian. Dalam rangka meningkatkan validitas internal, penulis menggunakan metode triangulasi. Hasil penelitian menunjukkan kinerja program unggulan Bupati TTU belum optimal karena pengembalian dana bergulir ternyata bersumber dari hasil usaha di luar program unggulan tersebut, hal ini disebabkan masih rendahnya koordinasi antar OPD sehingga terjadi over lapping di level implementasi, sedangkan secara internal belum ada instrumen kontrol terhadap tenaga lapangan, selain itu proses rekrutmen tenaga pendamping cenderung dipolitisasi, sehingga berpengaruh terhadap kapabilitas tenaga pendamping lapangan. Untuk itu pemerintah perlu membentuk tim khusus untuk memonitoring dalam rangka meningkatkan akselerasi antar OPD.

\section{Pendahuluan}

Pembangunan sektor pertanian memiliki peran yang sangat strategis, karena tidak hanya berperan dalam peningkatan perekonomian masyarakat pedesaan, namun juga aspek pemberdayaan untuk mewujudkan kemandirian sosial ekonomi masyarakat desa. Selama ini,dimensi sosial politik kurang mendapat perhatian dari pemangku kebijakan di Kabupaten Timor Tengah Utara (TTU) dalam merumuskan kebijakan pembangunan sektor pertanian. Para pengambil kebijakan cenderung terjebak pada aspek teknis prosedura dalam menentukan indikator keberhasilan suatu kebijakan. Padahal, aspek sosial politik juga menjadi determinan yang menentukan bagi keberhasilan dan keberlanjutan suatu program seperti Desa Mandiri Cinta Petani (Sari Tani). Hal ini ditengarai karena masih minimnya koordinasi antar Organisasi Perangkat Daerah (OPD) dan politisasi kebijakan populis tersebut sekedar sebagai intrumen politik akomodasi elite governing kepada aktor-aktor di lingkaran kekuasaannya. Akibatnya, kinerja OPD yang terkait dengan pelaksanaan program tersebut relatif belum optimal. Untuk itu, studi ini hendak mendeskripsikan pelaksanaan kebijakan sektor pertanian dalam perspektif sosio politik

Karakteristik wilayah Kabupaten TTU merupakan lahan keringyang mencapai 30,18\% dari keseluruhan luas daratan namun kaya dengan kandungan mineral (Rencana Pembangunan Jangka Menengah Daerah/RPJMD TTU 2016-2021). Pemerintah daerah telah melakukan optimalisasi sumber daya alam untuk mengejar pertumbuhan dan pendapatan asli daerah (PAD), namun dalam tiga tahun terakhir ini eksploitasi terhadap sumber daya alam tersebut dihentikan setelah pemerintah daerah menerapkan konsep green economy dengan merumuskan pembangunan ekonomi berbasis pertanian. Konsep ini sesuai dengan karakter masyarakat pedesaan yang mana $57,7 \%$ berprofesi sebagai petani (BPS TTU, 2015).

Salah satu isu strategis yang menjadi acuan dalam penyusunan strategi pembangunan Kabupaten TTU adalah pengembangan dan pemberdayaan ekonomi masyarakat berbasis pertanian (RPJMD TTU 2016-2021), yang bertujuan untuk meningkatkan produktivitas ekonomi berbasis pertanian dan pengentasan kemiskinan. Namun, kinerja pembangunan terutama sektor pertanian belum menunjukkan hasil yang maksimal karena masih tingginya jumlah keluarga pra sejahtera di pedesaan yang mencapai $61,5 \%$ dan dalam kurun waktu tiga tahun peran sektor pertanian terhadap Produk Domestik Regional Bruto (PDRB) menurun menjadi 47,80\% (BPS TTU, 2016).

Hal ini tidak sebanding dengan jumlah program pemberdayaan masyarakat dengan berbagai variannya yang diterima setiap desa. Program pembangunan yang berorientasi pada pemberdayaan masyarakat dengan sasaran petani baik kebijakan di tingkat provinsi maupun kabupaten cukup banyak. Misalnya, di tingkat provinsi ada Program Anggaran Kesejahteraan Masyarakat (Anggur Merah) dengan tujuan untuk meningkatkan ekonomi produktif masyarakat pedesaan. Program ini di oleh Bupati TTU direplikasi menjadi Program Sari Tani untuk pengembangan kegiatan ekonomi produktif di pedesaan. Selain itu, program bantuan pertanian seperti penyaluran pupuk bersubsidi, benih dan bibit tanaman maupun prasarana produksi pertanian seperti handtracktor sebagai stimulus bagi peningkatan produksi pertanian juga terus disalurkan kepada petani. Bahkan dari Dinas Pertanian Tanaman Pangan dan Perkebunan, Badan Ketahanan Pangan dan Pelaksana Penyuluhan (BKP3) dan Badan Pemberdayaan Masyarakat dan Pembangunan Desa (BPMPD) Kabupaten TTU terus melakukan pendampingan dengan memberikan bantuan pendampingan dan penyuluhan bagi peningkatan keterampilan petani melalui tenaga penyuluh atau pendamping lapangan.
Disparitas antara tujuan ideal dengan hasil pembangunan pemberdayaan masyarakat sektor pertanian tersebut menunjukkan pada tahapan formulasi sampai dengan implementasi kebijakan cenderung kurang sinergis. Hal ini terjadi karena adanya kecenderungan sifat ego sektor, terbatasnya dukungan anggaran, kemampuan sumber daya manusia (SDM), distrosi data dan informasi, multi tafsir implementor dalam menerjemahkan kebijakan dan aspek politis. Pada ranah birokrasi, proses formulasi kebijakan maupun adminsitrasi tidak bisa dipisahkan dari politik (Waldo, 1948 dalam Frederickson, dkk., 2012), sehingga pada tahap implementasi ada kecenderungan terjadi conflict of interest para aktor yang terlibat didalamnya.

Program Sari Tani yang bertujuan untuk menjawab kompleksitas persoalan di masyarakat seharusnya tidak hanya dimaknai sekedar ritus prosedural, namun juga bersifat politis dan multilinier. Kebijakan pembangunan sektor pertanian seperti halnya Sari Tani bertujuan untuk pemberdayaan masyarakat desa melalui penciptaan peluang usaha kreatif, persiapan dana pensiun petani dan menjaga kelestarian ekosistem melalui penerapan teknologi pertanian yang disesuaikan dengan karakteristik alam Kabupaten TTU yaitu lahan kering. Kebijakan populis tersebut, ternyata telah tereduksi oleh ide dan kepentingan para aktor yang terlibat dalam proses formulasi sampai dengan pelaksanaannya di lapangan. Dengan demikian, program yang secara normatif mempunyai tujuan yang baik, pada ranah perencanaan telah diintervensi oleh kepentingan politis, sehingga berimplikasi pada tataran implementasinya, karena pada awalnya memang telah diselimuti oleh motif politis sehingga kebijakan tersebut cenderung elitis.

Kajian sejenis tentang pengentasan kemiskinan telah menjadi perhatian akademisi dengan berbagai pendekatannya. Dima (2016) menemukan bahwa pelaksanaan program PKP di kabupaten TTU terkendala oleh keterbatasan sumber daya yang dimiliki petani sehingga belum mampu mengadopsi inovasi pertanian. Sedangkan penelitian Bekun dan Tiza (2016) menemukan bahwa transformasi kewirahusahaan di ranah masyarakat dalam program Sari Tani belum optimal karena disebabkan sikap dan perilaku masyarakat yang masih terikat dengan adat istiadat setempat. Dengan demikian, studi terdahulu cenderung fokus pada permasalahan pada kelompok sasaran, bukan pada ranah implementor kebijakan.

Terkait dengan hal tersebut, studi ini lebih fokus pada aspek sosial politik yang mengkaji pada proses pelaksanaan program Sari Tani di ranah birokrasi maupun di ranah masyarakat. Asumsi ini berangkat dari pemikiran bahwa selama ini indikator keberhasilan sebuah program semata-mata hanya didasarkan pada aspek teknis prosedural yang telah dirumuskan dalam suatu petunjuk teknis sehingga tidak mampu mengatasi akar permasalahan kebijakan karena cenderung abai terhadap aspek sosial-politik.

Aspek sosio-politik ini cenderung tidak pernah diperhatikan dalam sebuah kebijakan baik dalam mengukur keberhasilan maupun mengantisipasi ketika terjadi keragaman respon terhadap kebijakan tersebut. Akibatnya, ketika terjadi permasalahan di lapangan dan cenderung tidak terselesaikan, permasalahan tersebut menjadi problem kebijakan karena tidak mampu menyelesaikan permasalahan pada setiap level kebijakan

Konsep sinergitas dalam penelitian ini menggunakan pendapat Covey (1993) yang menyatakan bahwa untuk menghasilkan keluaran yang lebih baik perlu adanya kombinasi dan kesamaan pandang yang saling menghargai antar komponen. Sedangkan konsep kinerja mengadopsi pendapat Mahmudi (2010) dengan indikator yang meliputi input, proses, output, outcome, dan dampak Selain itu, konsep Grindle (1980) digunakan sebagai pisau analisis dalam rangka menjelaskan dinamika sosio politik kebijakan. Sedangkan dari aspek level analisis tindakan, penelitian ini menggunakan konsep Parsons (1995) 
untuk membantu menjelaskan peran masing-masing aktor dalam implementasi kebijakan dari dimensi struktural.

Dengan demikian, kajian terhadap kebijakan pembangunan dengan fokus pelaksanaan kebijakan sektor pertanian di Kabupaten TTU dinilai urgen dalam rangkamemberikan sumbangan terhadap studi kebijakan dan memberikan kontribusi bagi Pemerintah Daerah dalam perumusan kebijakan pembangunan yang sesuai dengan karakteristik lokal (local wisdom) dan potensi lokal yang berbasis pada karakteristik wilayah TTU yaitu lahan kering.

\section{Metode}

Penelitian ini merupakan penelitian deskriptif analisis yaitu menganalisis proses kebijakan pembangunan sektor pertanian dengan fokus pada sinergitas dan kinerja Organisasi Perangkat Daerah (OPD) dalam pelaksanaan program Sari Tani yang dilaksanakan dari bulan Mei sampai dengan bulan Juli tahun 2017. Ukuran sinergitas dalam penelitian ini menggunakan konsep Covey (1993), ukuran kinerja mengadopsi pendapat Mahmudi (2010) dan konsep implementasi kebijakan dari Grindle (1980) digunakan sebagai pisau analisis dalam rangka menjelaskan dinamika sosio politik kebijakan, sedangkan konsep Parsons (1995) untuk membantu menjelaskan peran masing-masing aktor dalam implementasi kebijakan dari dimensi struktural. Hasil analisis sebagai pernyataan pengetahuan berdasarkan perspektif-konstruktif berupa, informasi dan makna-makna yang bersumber dari informan, dengan tujuan untuk membangun teori atau pola pengetahuan tertentu (Creswell, 2010), dengan mencoba menyajikan pandangan subjek yang diteliti tentang fenomena yang terjadi sehari-hari (Yin, 2002) terutama yang terkait dengan proses pelaksanaan program Sari Tani di Kabupaten TTU.

Data primer diperoleh melalui wawancara langsung dengan informan yang meliputi pimpinan dan staf Dinas Pemberdayaan Masyarakat Desa (DPMD) (sebelumnya bernama Badan Pemberdayaan Masyarakat dan Pembangunan Desa (BPMPD), Dinas Pertanian, Dinas Peternakan dan Badan Ketahanan Pangan dan Pelaksana Penyuluhan (BKP3) dengan teknik purposive. Untuk memenuhi aspek representatif dan obyektifitas analisis penelitian, masyarakat sasaran di-cluster-kan ke dalam tiga tipologi berdasarkan geografis sesuai dengan karakteristik wilayah Kabupaten TTU, yaitu; 1) masyarakat yang berdomisili di daerah pegunungan, 2) masyarakat yang berdomisili di daerah dataran, dan 3) masyarakat yang berdomisili di daerah pesisir pantai. Selanjutnya, secara administratif pemerintahan, dari 24 kecamatan di TTU dipilah-pilah ke dalam tipologi geografis dan diambil tiga kecamatan sebagai wilayah penelitian, yaitu kecamatan Miomaffo Timur, kecamatan Biboki Utara dan kecamatan Insana Utara. Dari tiga kecamatan terpilih, diambil satu desa untuk masing-masing kecamatan sebagai lokasi penelitian.

Langkah terakhir untuk menentukan informan masyarakat ditentukan dengan menggunakan kriteria, yaitu; 1) masyarakat yang berprofesi sebagai petani, 2) masyarakat yang mendapatkan bantuan pertanian dari program Sari Tani, dan 3) masyarakat yang pernah mendapatkan bantuan keterampilan berupa penyuluhan maupun pendampingan. Instrumen wawancara berupa pedoman wawancara yang dirancang secara umum, tidak terstruktur dan bersifat terbuka, pertimbangannya untuk mempermudah peneliti dalam memunculkan pandangan dan opini dari informan. Pengamatan atau observasi dilakukan untuk mengamati secara mendetail aktivitas pelaksana kebijakan dan masyarakat, sehingga makna dari pembicaraan, sikap maupun perilaku para aktor tersebut mudah diinterpretasikan oleh peneliti. Selama penelitian, peneliti juga mengumpulkan data sekunder berupa dokumen-dokumen publik seperti naskah kebijakan pemerintah maupun laporan-laporan instansi terkait dan media massa.Proses pengambilan data lapangan berhenti ketika data yang terkumpul dirasa telah sesuai dengan kebutuhan dalam menjawab pertanyaan penelitian.

Penelitian ini melakukan pengolahan data melalui tahapan reduksi data, penarikan kesimpulan dan verifikasi. Dalam rangka meningkatkan validitas internal, penulis menggunakan metode triangulasi (Moleong, 2001) dengan membandingkan dan mengecek balik derajat kepercayaan satu informasi yang diperoleh melalui wawancara pada waktu yang berbeda.

\section{Hasil dan Pembahasan}

Anggaran yang dialokasikan untuk kebutuhan penyaluran bantuan dana Sari Tani mengalami peningkatan setiap tahunnya. Berdasarkan data dari Dinas Pemberdayaan Masyarakat Desa, pada tahun anggaran 2012 dana yang disalurkan kepada 24 desa sebesar Rp 7.200.000.000,00. Pada tahun 2013 alokasi anggaran untuk program unggulan bupati ini naik menjadi Rp.10.800.000.000,00 yang disalurkan kepada 36 desa. Memasuki tahun ketiga anggaran untuk program Sari Tani kembali naik hampir tiga kali lipat, yaitu sebesar Rp.30.300.000.000,00 yang disalurkan kepada 101 desa. Dengan demikian, total dana Sari Tani yang telah disalurkan sebesar Rp.48.300.000.000,00 dengan jumlah desa sasaran mencapai 161 desa, yang mana besaran dana setiap desa rata-rata mencapai Rp.300.000.000,00.

Rincian penggunaan dana Sari Tani yang disalurkan ke setiap desa sebesar Rp.300.000.000,00 tersebut tidak seluruhnya disalurkan kepada kelompok tani, namun juga digunakan untuk biaya operasional lain. Biaya operasional lain tersebut sebesar Rp50.000.000,00 yang dibagi dalam dua item kegiatan yaitu sebesar Rp.40.000.000,00 untuk biaya operasional Unit Pengelola Sari Tani (UPST) selama 3 tahun dan Rp10.000.000,00 digunakan untuk biaya pelatihan anggota UPST, sehingga untuk merealisasikan pengembangan program unggulan kabupaten seperti; paronisasi sapi, penggemukan babi, usahatani jagung, kacang tanah dan bawang putih siung tunggal sebesar Rp.250.000.000,00. Dari aspek sumber daya manusia, pelaksanaan program Sari Tani didukung oleh staf dari Dinas Pemberdayaan Masyarakat Desa (sebelumnya bernama Badan Pemberdayaan Masyarakat dan Pemerintah Desa) dan tenaga penyuluh dari Dinas Pertanian dan Dinas Peternakan serta tenaga pendamping masyarakat. Pemerintah kecamatan berperan sebagai koordinasi yang membawahi desa-desa yang menerima bantuan Sari Tani. Seluruh kegiatan program Sari Tani yang berada dalam ranah kecamatan ditangani oleh Tim Pelaksana Program Kecamatan (TPPK) yang terdiri dari aparat pemerintah kecamatan, koordinator petugas penyuluh lapangan (PPL) dan mantri tani. Tim Pelaksana Program Kecamatan ini selalu melakukan koordinasi dengan Dinas Pemberdayaan Masyarakat Desa.

Sedangkan di tingkat desa secara struktural kepala desa berfungsi sebagai ketua Tim Koordinasi Tingkat Desa, sedangkan pelaksana program Sari Tani di tingkat desa dilaksanakan oleh Unit Pengelola Sari Tani (UPST) dan Pendamping Kelompok Masyarakat (PKM) bersama mitra kerja yang berasa dari lembaga swadaya masyarakat (LSM) lokal. Petugas UPST dipilih oleh tim koordinasi tingkat desa melalui musyawarah desa dan ditetapkan oleh kepala desa melalui surat keputusan kepala desa. Sedangkan tenaga PKM direkrut langsung oleh Dinas Pemberdayaan Masyarakat Desa sebagai tenaga kontrak. Susunan pengurus unit pengelola Sari Tani ini terdiri dari ketua, sekretaris, bendahara, seksi verifikasi dan seksi data dan publikasi.

Kehadiran program unggulan ini dilaksanakan dengan target output berupa pengurangan kepala keluarga miskin dalam jangka waktu lima tahun. Adapun target output tersebut secara progresif ditentukan secara bertahap, pada tahun 2010 jumlah kepala keluarga miskin tercatat sebesar 36.225 kepala keluarga $(65,62 \%)$ dan pada tahun 2015 jumlah keluarga miskin turun menjadi 26.012 kepala keluarga $(47,12 \%)$. Persentase penurunan keluarga miskin per tahun sebesar $3,7 \%$, sehingga akumulasi penurunan persentase kemiskinan di kabupaten Timor Tengah Utara selama lima tahun sebesar $18.53 \%$. Berdasarkan data Badan Pusat Statistik sampai tahun 2017 tercatat angka kemiskinan sebesar 34,10 \%. Hal ini menunjukkan bahwa dampak yang ditimbulkan dari pelaksanaan program Sari Tani telah berhasil menurunkan angka kemiskinan karena telah menciptakan lapangan kerja di sektor pertanian. Namun klaim pemerintah yang didukung dengan data tersebut cukup kontroversial jika dibandingkan kenyataan di lapangan yaitu tingginya tunggakan yang dialami oleh kelompok tani.

Pada tahun 2012 menunjukkan bahwa bantuan yang disalurkan sebesar Rp.844.435.800,00 dengan tingkat pengembalian pada tahun berikutnya sebesar Rp.374.215.781,00. Dengan demikian pada tahun pertama penyaluran bantuan telah terjadi tunggakan oleh kelompok tani pada ketiga kecamatan sebesar Rp.470.220.019,00 atau mencapai 55,68\%. Tingginya tunggakan pengembalian dana Sari Tani tersebut disebabkan pada usaha paronisasi sapi yang dinilai kurang berhasil. Kegagalan paronisasi sapi berdasarkan pengakuan kelompok tani disebabkan karena faktor perubahan cuaca yang tidak menentu, sehingga berimbas pada langkanya sediaan pakan ternak.

Pada penyaluran tahun 2013 bantuan yang digulirkan kepada kelompok tani sedikit mengalami penurunan menjadi sebesar Rp.832.273.000,00. Hal ini disebabkan karena menurunnya jumlah kelompok tani dan jenis usaha produktif yang membutuhkan modal lebih kecil seperti usaha bawang putih dan penggemukan babi. Namun dari data yang diperoleh menunjukkan tingkat pengembalian dana bergulir tersebut hanya sebesar Rp.247.624.000,00. Berdasarkan pengakuan informan, permasalahan tersebut disebabkan gagalnya kelompok tani dalam pengelolaan usaha produktifnya tersebut, sehingga terjadi tunggakan sebesar Rp.584.649.000,00 atau mencapai 70,2\%. Hal ini menunjukkan persentase tunggakan pada tahun kedua lebih besar dibandingkan pada penyaluran tahun pertama.

Selanjutnya, pada tahun 2014 penyaluran bantuan kepada kelompok tani meningkat drastis dibandingkan tahun 2013, yaitu sebesar Rp.3.114.793.200,00. Kenaikan ini disebabkan bertambahnya jenis usaha dan jumlah kelompok tani yang menjadi sasaran program unggulan Bupati ini. Namun, seperti dua tahun sebelumnya, tingkat pengembalian dana bergulir tersebut hanya mencapai Rp.1.007.014.681,00, sedangkan tunggakan para kelompok tani sasaran jika diakumulasi mencapai Rp.2.107.778.519,00 atau sebesar $67,7 \%$.

Secara keseluruhan, dana Sari Tani yang digulirkan kepada kelompok sasaran mencapai Rp.4.791.502.000,00 dengan tingkat pengembalian sebesar Rp.1.628.854.462,00 atau hanya sebesar 34\%, sedangkan dana bergulir yang mengalami tunggakan di tingkat kelompok tani sebesar Rp.3.162.647.538,00 atau $66 \%$

Berdasarkan rekapitulasi data dari Dinas Pemberdayaan Masyarakat Desa kabupaten Timor Tengah Utara, sampai dengan tahun 2017, alokasi anggaran untuk pelaksanaan program Sari Tani mencapai Rp.33.979.367.111,00 yang disalurkan ke 161 desa yang terdapat di kabupaten Timor Tengah Utara dengan bunga sebesar Rp.2.091.058.165,00, maka kewajiban yang harus dikembalikan oleh seluruh kelompok tani sebesar Rp.36.111.518.676,00.

Namun sampai dengan bulan Februari 2017, tingkat pengembalian pokok dan bunga di tingkat kelompok tani sangat rendah yaitu sebesar Rp.13.678.956.150,00 atau 38\%. Sedangkan tunggakan yang harus dikembalikan oleh kelompok tani di tingkat kabupaten mencapai Rp.22.395.314.762,00 atau 62\%, namun angka ini masih lebih kecil jika 
dibandingkan dengan persentase tunggakan di tiga kecamatan yang sebesar 64 $\%$, data untuk tingkat kabupaten secara terperinci disajikan dalam tabel 1.

Jika mencermati adanya disparitas antara bantuan yang telah disalurkan dengan tingkat pengembalian di kelompok tani yang cukup besar, maka perlu dikaji kembali klaim pemerintah daerah yang menyatakan bahwa program Sari Tani telah memberikan dampak pada tingkat penurunan angka kemiskinan di pedesaan. Dari penelusuran di lapangan terutama di tingkat kelompok tani menunjukkan bahwa rata-rata mereka yang mengelola dana Sari Tani mengalami kesulitan dalam mengembalikan pinjaman pokok berserta dengan bunganya. Terdapat variasi alasan mengapa mereka mengalami kesulitan dalam mngembalikan dana bergulir tersebut. Bagi para kelompok tani yang mengusahakan paronisasi sapi dan usaha penggemukan babi, alasan yang disampaikan adalah kematian ternak mereka akibat terserang suatu penyakit, yang mana para petani tersebut tidak mampu mengatasinya akibat tidak memiliki pengetahuan untuk itu. Terkait dengan kasus kematian ternak sapi maupun babi tersebut tidak semata-mata menjadi kesalahan kelompok tani. Berdasarkan pengakuan para petani maupun Unit Pelaksana Sari Tani, kendala yang dihadapi oleh peternak adalah kurang intensifnya kunjungan pendamping lapangan baik tenaga penyuluh pertanian baik dari Dinas Pertanian maupun dari Dinas Peternakan dan pendamping kelompok masyarakat yang direkrut khusus untuk mendampingi kelompok tani. Namun khusus untuk pendamping kelompok masyarakat yang direkrut oleh Dinas Pemberdayaan Masyarakat Desa hanya melakukan pendampingan dari aspek manajemen pengelolaan keuangan dan pembuatan laporan.

Tabel 1. Jumlah Pinjaman, Pengembalian dan Tunggakan Dana Sari Tani perJenis Usaha di Kabupaten Timor Tengah Utara Tahun 2017

\begin{tabular}{lccc} 
Jenis Usaha & $\begin{array}{c}\text { Pinjaman } \\
(\mathrm{Rp})\end{array}$ & $\begin{array}{c}\text { Pengembalian } \\
(\mathrm{Rp})\end{array}$ & $\begin{array}{c}\text { Tunggakan } \\
(\mathrm{Rp})\end{array}$ \\
\hline Paronisasi sapi & 27.843 .475 .265 & $\begin{array}{c}11.851 .089 .246 \\
(42,6 \%)\end{array}$ & $\begin{array}{c}15.992 .915 .630 \\
(57,4 \%)\end{array}$ \\
& & 1.525 .451 .185 & 6.155 .524 .780 \\
Penggemukan babi & 7.718 .753 .340 & $(21 \%)$ & $(79 \%)$ \\
& & 79.728 .250 & 17.587 .750 \\
Kacang tanah & 97.316 .000 & $(82 \%)$ & $(18 \%)$ \\
& & 166.034 .719 & 150.153 .352 \\
Jagung & 316.188 .071 & $(52,5 \%)$ & $(47,5 \%)$ \\
& & 56.652 .750 & 79.133 .250 \\
Bawang putih lokal & 135.786 .000 & $(42 \%)$ & $(58 \%)$ \\
\hline \multirow{2}{*}{ Jumlah } & 36.111 .518 .676 & 13.678 .956 .150 & 22.395 .314 .762 \\
& & $(38 \%)$ & $(62 \%)$ \\
\hline
\end{tabular}

Selain itu, kurang efektifnya koordinasi lintas sektor mengakibatkan lemahnya kontrol terhadap pembelian anakan sapi oleh petani yang dibawah standar, akibatnya ternak yang mereka usahakan tidak bisa dijual dalam jangka waktu satu tahun. Termasuk dalam kasus ini adalah tindakan beberapa petani yang kurang menunjukkan rasa tanggung jawab dalam mengelola bantuan adalah mereka menggunakan ternak-ternak tersebut untuk kebutuhan konsumsi, terutama untuk kepentingan adat atau pesta, dan ketika pendamping lapangan menanyakan keberadaan Sapi atau Babi mereka, mereka hanya menjawab bahwa ternak mereka telah mati terserang penyakit.

Sikap dan perilaku yang ditunjukkan oleh petani berdasarkan keterangan dan pengakuan para petani yang mengusahakan paronisasi Sapi dan penggemukan Babi sejalan dengan data sekunder yang diperoleh dari Kepala Dinas Pemberdayaan Masyarakat Desa yang mana mereka mengalami kesulitan dalam pengembalian dana bergulir tersebut. Tercatat sampai dengan Februari 2017, realisasi tingkat pengembalian pokok usaha paronisasi sapi beserta bunganya hanya sebesar Rp.11.851.089.246,00 atau 42,56\%, sedangkan tunggakan pokok beserta bunganya mencapai Rp.15.992.915.630,00 atau mencapai $57,44 \%$. Yang lebih memprihatinkan adalah di tingkat petani yang melakukan usaha penggemukan babi yang mana tingkat pengembaliannya hanya sebesar 19,76\% atau sebesar Rp.1.525.451.185,00 dan jumlah tunggakan sampai bulan Februari 2017 sebesar Rp.6.155.524.780,00 atau sebesar 79,24\%.

Sebagian masyarakat yang berhasil mengembalikan bantuan Sari Tani bukan berasal dari hasil usaha produktif dari program Sari Tani, namun berasal dari usaha di luar program unggulan ini. Kasus seperti ini dalam monitoring maupun evaluasi oleh Dinas Pemberdayaan Masyarakat Desa dianggap bukan sebagai kegagalan program. Pemerintah daerah hanya menggunakan ukuran keberhasilan dari aspek tingkat pengembalian bantuan dan tidak pernah memperhitungkan dari mana asal uang yang digunakan untuk mengembalikan bantuan tersebut. Jika pemerintah terus permisif dengan kasus-kasus seperti, maka akan terjadi bias dalam menentukan keberhasilan suatu program.

Selain kendala tunggakan pengembalian bantuan dana, dari aspek proses pelaksanaan program Sari Tani juga mengalami berbagai masalah, seperti; 1) Adanya pendobelan nama yang sama pada kelompok tani yang sudah menerima bantuan dari program lain di tingkat provinsi. Kasus ini disebabkan karena adanya kesalahan di tingkat desa dalam melakukan identifikasi masyarakat yang layak mendapatkan bantuan dari program Sari Tani. Hal ini menunjukkan tingkat koordinasi baik vertikal maupun horisontal antar institusi terkait kurang sinergis. 2) Adanya konflik internal di tingkat desa antara kepala desa dengan pengurus unit pengelola Sari Tani di desa Haekto akibat kesalahpahaman menyangkut pencairan penyaluran bantuan kepada kelompok tani dan biaya operasional unit pengelola Sari Tani yang mana kepala desa tidak bersedia menandatangi kuitansi. Hal ini juga menjukkan bahwa masing-masing aktor terkait di tingkat desa belum memahami secara baik tugas dan fungsi yang menjadi tanggung jawabnya. 3) Adanya kesalahpahaman antara pendamping kelompok masyarakat dengan pemerintah kecamatan di Noemuti Timur. Hal ini menunjukkan bahwa tenaga pendamping kelompok masyarakat belum menguasai prosedur pelaporan secara berjenjang, yang mana sesuai dengan petunjuk teknis mereka wajib melakukan koordinasi dengan pemerintah kecamatan sebagai perpanjangan tangan dari bupati sebagai penanggungjawab program sari Tani. Selain itu, perilaku yang ditunjukkan oleh tenaga pendamping kelompok masyarakat kurang menghiraukan peran Dinas Pemberdayaan Masyarakat Desa sebagai pengendali program di tingkat kabupaten. Berdasarkan pengakuan beberapa sektretaris camat, lemahnya koordinasi di tingkat tenaga pendamping kelompok masyarakat, unit pengelola Sari Tani, kepala desa sampai kecamatan tidak terlepas dari penerapan otonomi desa berdasarkan Undang-Undangn Nomor 6 Tahun 2016 tentang Desa, yang mana terjadi reduksi peran kecamatan dalam pelaksanaan pembangunan di tingkat desa pasca penerapan undang-undangn tersebut, sehingga beberapa kepala desa merasa tidak perlu melakukan koordinasi dengan camat namun langsung kepada bupati. 4) Pendamping kelompok masyarakat mengalami kesulitan dalam melakukan penagihan kepada kelompok tani yang telah jatuh tempo. Berdasarkan pengakuan dari salah satu staf Dinas Pemberdayaan Masyarakat Desa solusi yang diambil adalah dengan mengganti tenaga pendamping kelompok masyarakat dari anak asli desa setempat, sehingga diharapkan akan mempermudah bagi Dinas Pemberdayaan Masyarakat Desa melakukan penagihan pinjaman dana Sari Tani kepada kelompok tani.

\section{Simpulan}

Lemahnya koordinasi lintas OPD menyebabkan terjadinya over lapping ditingkat lapangan terutama dalam pelaksanaan pendampingan dimasyarakat. Sedangkan dari aspek internal masing-masing OPD ternyata belum memiliki instrumen kontrol dan mekanisme sanksi terkait dengan kinerja tenaga pendamping lapangan. Akibatnya dalam proses pengembalian dana bergulir dalam Program Sari Tani masih ada kelompok masyarakat yang menyalahgunakan dana bantuan tersebut akibat lemahnya kinerja tenaga pendamping. Selain itu, dalam pengembalian dana bergulir ternyata bersumber dari hasil usaha di luar program unggulan tersebut, hal ini disebabkan masih rendahnya koordinasi antar OPD dan monitoring di internal OPD. Kompleksitas permasalahan yang terjadi tidak terlepas dari lemahnya koordinasi sehingga mengakibatkan kinerja institusi terkait juga kurang optimal.

\section{Pustaka}

Bekun, Stefanus dan Agustinus L. Tiza. 2017. Pemberdayaan MasyarakatPedesaan Melalui Transformasi Nilai-Nilai Kewirausahaan dalam Pelaksanaan Program Desa Mandiri Cinta Petani (Sari Tani) di Kecamatan Insana, Kabupaten Timor Tengah Utara. Agrimor 2 (1) 4-9. Jurnal Agribisnis Lahan Kering 2017. Universitas Timor.

Covey, Stephen, R. 1993. Principles Centered Leardership. New York. Franklin Covey.

Creswell, John, W. 2010. (alih bahasa, AchmadFawaid). Research Design Pendekatan Kualitatif, Kuantitatif dan Mixed. Pustaka Pelajar. Yogyakarta.

Dima, Yuliana Kurniawati.2016. Evaluasi Pelaksanaan dan Strategi Keberlanjutan Program Padat Karya Pangan di Kabupaten Timor Tengah Utara. Jurnal Ilmiah Administrasi Publik Vol. 2 No. 4, pp 171176. Universitas Brawijaya.

Frederickson, H.G., K.B. Smith,C.W. Larimer, M.J. Licari. 2012. The Public Administration Theory Primer. Second Edition. Boulder, Colorado: Westview Press.

Grindle, Merilee, S. 1980. Politics and Policy Implementation in the Third World. New Jersey. Princeton University Press.

Mahmudi, 2010. Manajemen Kinerja Sektor Publik. UPP STIM YKPN. Yogyakarta.

Moleong, Lexy, J. 2001, Metode Penelitian Kualitatif. PT. RemajaRosdakarya. Bandung

Parsons, W. 1995. Public Policy: An Introduction to the Theory and Practice of Policy Analysis. Cheltenham, UK: Edward Elgar.

Yin, Robert, K. 2002. (alih bahasa Mudzakir) Case Study Research Design and Methods. PT. Raja Grafindo Persada. Jakarta. 